Корніснко Інокентій

доктор психологічних наук, доцент, доцент кафедри психології

Мукачівського державного університету, http://orcid.org/0000-0003-1451-4128

DOI https://doi.org/10.35619/praprv.v1i15.201

\title{
РИЗИК ЯК ЕЛЕМЕНТ ЖИТТЕВОГО ПРОСТОРУ ОСОБИСТОСТІ: ТЕОРЕТИЧНИЙ КОНТЕКСТ
}

Анотація. Стаття присвячена висвітленню проблеми потреби встановлювати контроль над факторами ризику та невизначеності через теоретичний аналіз місия ризику y життєвому просторі особистості. У статті здійснено різнобічний аналіз розуміння ризику у психології, визначено оціночну дихотомію ризикованість / не ризикованість. Виявлено риси схильної до ризику особистості: погане самоврядування, послаблений інстинкт самозбереження, імпульсивність, ригідність, індивідуалістичність, тощо. Розглянуто питання нормативності особистості, яка є наслідком особистої потенційності з двох точок зору: як «тілесна» нормативність, яка розглядається насамперед через адаптацію, та сочіальну «надприродну» нормативність. Виявлено параметри ризику через очінку невизначеності та діалектику дихотомії «успіх - невдача». Розглянуто схильність до ризику, ризик-рису як стійку системну інтегральну властивість особистості, полікомпонентну за своєю структурою, щзо включає формально-динамічні, якісні, змістовні, сочіально-імперативні характеристики. Проаналізовано зв'язок очінки ризику з иінностями $i$ нормами сочіального характеру із врахуванням соціокультурного контексту. Встановлено, що ризик виникає як показник потенційності та невизначеності результату й може трактуватися як показник відкритості особистості.

Ключові слова: ризик, ризикованість, життєвий простір, невизначеність, самодетермінація особистості.

Постановка проблеми. Характерною рисою нашого часу $\epsilon$ актуальна потреба встановлювати контроль над факторами ризику та невизначеності. Питання щодо детермінантів ризикової поведінки отримують нову актуальність у часи карантину, коли психологів, управлінців, соціологів, політиків і просто громадян все більше цікавлять запитання, чому деякі люди свідомо нехтують безпекою найближчих, свідомо ігнорують правила безпечної поведінки, ідуть на ризик за відсутності життєвої необхідності у цьому. Відкритими залишаються запитання як цьому запобігти, або хоча б як із цією проблемою починати працювати. Ключовим початком дослідження може бути пошук саме детермінант ризикової поведінки, серед яких розглядають ситуації і обставини, набір певних властивостей особистості або наявність окремої характеристики, яка проявляється в стійкій схильності до ризикової поведінки. Ми вважаємо, що ці психологічні особливості можуть охоплювати досить широкий діапазон характеристик особистості. Вони можуть проявлятися в різних якостях і в різному ступені: від «ризикової сліпоти» суб'єкта до «ризикової проникливості», від «ризикової нечутливості» до «ризикової чутливості». Таким чином, можна вважати, що ризикогенність деяких людей полягає в тому, що вони своїми діями, поведінкою, через які проявляються певні риси їх особистості, збільшують ризикогенні ситуації, що виникають, а іноді і створюють їх навіть 3 нейтральних, 3 точки зору ступеня невизначеності (Саннікова та ін.) і саме через таку призму будуть свої стратегії життя i формують власний життєвий простір.

Аналіз останніх досліджень 3 проблеми. Ризик (від фр. risqué - наражатися на небезпеку) визначається як діяльність в умовах небезпеки, відсутності повної впевненості в успіху (Конюхов). Поняття готовності до ризику вперше з'явилося в США в 1960-і рр. Американські вчені Ховт і Стонер (Корнілова) зробили припущення, що за ступенем прояву 
готовності до ризику людей можна розділити на дві категорії: на «ризикуючих» i «обережних». Перші відрізняються високим рівнем домагань, прагненням до лідерства, здатністю і бажанням впливати на інших людей. Другі ж є нерішучими, обережними у виборі й в відносинах з іншими людьми і більш схильні до підпорядкування. Готовність до ризику може проявлятися як в діях, у поведінці людини, так і в його переживаннях і думках.

У психології під ризиком розуміється дія (поведінка), спрямована на визначену мету, досягнення якої пов'язане 3 небезпекою, загрозою ураженням, невдачею. Відповідно неризикована дія (поведінка) є більш виваженою, не пов'язаною з загрозою невдачі, поразки; дія, що здається більш надійною і безпечною (але не завжди є такою у реальності).

У літературі дихотомія ризикованість - не ризикованість часто розглядається як характеристика поведінки та у контексті поєднання особистісно-ситуаційних і соціальних факторів. Деякі автори виділяють особливий набір, комплекс рис особистості, який впливає на рівень ризикованості поведінки людини (Саннікова, 2007; Корнілова, 2003). Також існують ситуації, що провокують ризиковану поведінку людей. Встановлено, що агресивні люди з сильною потребою в домінуванні й самоствердженні більш схильні до ризику.

Ризик являє собою ситуацію вибору між двома допустимими варіантами дій: менш привабливим, але більш надійним і більш привабливим, але менш надійним, тобто результат якого проблематичний і пов'язаний з можливими несприятливими наслідками, де неуспіх тягне за собою втрату (фізична загроза, біль, соціальні санкції). Ризик може бути пов'язаний 3 вибором такого варіанту дій, який йде врозріз 3 інструкціями, розпорядженнями, жорсткими правилами. Причому, якщо відступ від приписів призведе до позитивного результату, (успіху) в діяльності, то оцінка може бути не просто позитивною, але й дуже високою. У деяких роботах встановлено, що схильність до ризику пов'язана 3 багатьма якостями особистості, такими як тривожність, конфліктність, агресивність, прагнення до гострих відчуттів (Kogan, Wallach, 1967). До рис схильної до ризику особистості відносять екстремально виражену потребу домінувати над іншими людьми. Крім того, зазначають, що таким людям властиво: погане самоврядування (панування емоційної сфери над раціональною), послаблений інстинкт самозбереження, імпульсивність, наявність «заряду ризиковості», ригідність, індивідуалістичність, гіперактивність, ініціативність, авантюрність намірів, комплекс вседозволеності, схильність до обману (Саннікова, 2003).

У вітчизняній науці представлено багато праць, що охоплюють ризик та ризикованість із різних позицій. Дослідження психологічних аспектів ризик-менеджменту в процесі прийняття управлінських рішень і визначення когнітивних ілюзій при врахуванні ризику в діяльності підприємства було здійснено Федуловою, і має акцент саме на процесі прийняття управлінського ризику (Федулова, 2018). Також було детально проаналізовано поняття ризику та невизначеності; розглянуто об'єктивні та суб'єктивні складові ризику, наведено класифікацію невизначеності як основного джерела ризику. Пропонується якісне визначення ризику та розглядаються фактори впливу на ризик (Рішняк, 2003). Широко розглядалися теоретичні аспекти формування та розвитку системи управління ризиками: було виділено основні підходи у дослідженні ризиків та сформульовано перелік етапів управління ризиком, визначено основні принципи побудови системи управління ризиками (Непомнящий, 2017).

Окремим напрямом розкривається сутність поняття ризик у системі вищої освіти і вплив психологічних ризиків на професійне становлення майбутніх спеціалістів у період їх навчання. Розглянуто основні напрямки психологічних досліджень ризиків в освітньому середовищі, виокремлено види і такі якості психологічних ризиків, як невизначеність та альтернативність, запропоновано піраміду ризиків суб'єкта навчання у освітньому середовищі та визначено роль відповідальності у процесі нівелювання ризиків. Зауважено, що превентивним заходом запобігання ризику критичних рівнів $є$ впровадження різних форм психологічної підтримки та психологічного супроводу особистості протягом навчання 3 метою розвитку відповідальності особистості. Встановлено, що відповідальність як професійно важлива якість дозволяє контролювати критичні рівні розвитку психологічних 
ризиків у певних ситуаціях навчання за допомогою психологічного ресурсу (Алексєєва, 2013).

У методичному аспекті - розроблено комп’ютерну методику «Мішень», яка дозволяє у штучно створеній експериментальній ситуації вимірювати схильність до ризику за відносно невеликий проміжок часу (Безродний, 2010). Апробація методики свідчить про іiі можливе використання для професійного відбору на потенційно небезпечні види діяльності. Тим не менш, питання ризику, як елементу життєвого простору особистості, як стійку поведінкову детермінанту особистості, яка $є$ будівним елементом того самого життєвого світу особистості у вітчизняній психології широко не розглядали. Актуальність даного питання у період карантину і нерозробленість даної тематики $є$ головним актуалізатором i мотиватором до розробки даної психологічної проблематики.

Метою статті $\epsilon$ теоретичний аналіз проблеми ризику у життєвому просторі особистості, вибір концептуально-філософських основ для майбутнього емпіричного дослідження ролі ризику у конструюванні особистісного життєвого простору.

Виклад основного матеріалу дослідження. Картина світу, за визначенням в психології - це уявлення про те, що можна чи не можна зробити в даній ситуації, що вигідно чи невигідно, що етично, що ні тощо, змінюється в ході розвитку суспільства, невичерпна за змістом і $є$ основою людської поведінки. Вона формується за допомогою отримання досвіду людиною у призмі суб'єктивного сприйняття. Смірнов розглядає картину світу як інтегральне утворення пізнавальної сфери особистості, яке виконує роль вихідного пункту й результату будь-якого пізнавального акту (Смірнов, 1985). В той самий час, картина світу містить у собі потенційно можливі шляхи подолання розриву між психологією пізнання й психологією особистості. В ній знаходиться «п'яте квазівимірювання» - «значеннєве поле», «система значень» (Леонтьєв, 1983). Значеннєва складова картини світу - організатор його цілісності, власне особистісний рівень уявлення світу.

Життєвий простір людини починає розширюватися від дитинства до зрілості, і є результатом певного структурування світу, виокремлення в ньому певної, особливо значимої i тісно пов'язаної із власними інтересами й прагненнями сфери, яка сприймається i переживається індивідом як «свій» світ. У створенні цього світу людина бере безпосередню участь, як за допомогою предметно-практичної, так i за допомогою «внутрішньої» діяльності, яка може бути співвіднесена із третьою, четвертою й п'ятою підструктурами робочої схеми структурної організації свідомості, яку запропонував Леонтьєв: механізмами осмислення, внутрішнім світом і рефлексією (Леонтьєв, 1999). Ця внутрішня діяльність являє собою особистісний рівень регуляції - саморегуляцію. Як регуляторна система, особистість конституюється функціями виділення себе 3 навколишнього світу: виділення, презентації й структурування своїх відносин з світом і підпорядкування своєї життєдіяльності стійкій структурі цих відносин, на противагу негайним імпульсам і зовнішнім стимулам (Леонтьєв, 1999). Для того, щоб ця регуляція здійснювалась, власні відносини з світом повинні бути якимось чином представлені суб'єктові в його свідомості, тобто, включені в його картину світу.

Сартр звільнив людину одночасно наражаючи на ще більшу проблему - проблему необхідності вибору. Тому екзистенціальний вибір пов'язаний перш за все з відповідальним та усвідомленим рішенням. Творчість як властивість особистості грунтується на свободі і виражає креативну активність у відношенні як життєвого простору, так і ціннісної структури особистості. Світовідчуття особистості, розуміння нею свого місця в світі дозволяють їй сформувати власний унікальний простір, побудований на значущих для неї принципах. Таким чином особистість, яка творить власну систему значимості, вибудовує відповідно до неї як просторову, так і часову характеристику. Процес творіння себе, своєї самості i, як наслідок, власного життєвого простору, грунтується на єдності свободи і відповідальності. Свобода і творчість є характеристики потенційності особистості. Людина - це проєкт, і саме тому, приймаючи екзистенціальне рішення, кожен з нас творить сам себе.

Ще однією суттєвою характеристикою людської реальності є іiї нормативність, тобто потреба у формуванні норм поведінки, які перетворюються в мотиваційні обставини 
індивідів як перед середовищем, так і перед самим собою. Пояснена таким чином, нормативність $є$ виразом непристосованості людини до навколишнього середовища. Це дає можливість стверджувати, що норма стає атрибутом людського буття, вимушено створеною самою людиною.

Нормативність людини є наслідком особистої потенційності. Вона може бути розглянута 3 двох точок зору. По-перше, це «тілесна» нормативність, під якою мається на увазі найжорстокіша регламентація всіх сторін людського існування. «Тілесна» нормативність людини формується завдяки іï тілу як біологічного організму. Первинна адаптація - опредметнення середовища за образом людини - грунтується на знанні власного тіла, його біологічного механізму. Нормативність, як система біологічних детермінант, дозволяє виживати. Вона являє собою захисну реакцію природи проти того, що в миследіяльності може бути гнітючим для індивіда і небезпечним для соціуму. Її аналогом можна вважати систему табу в стародавніх суспільствах, де накладалась заборона на певні види діяльності, нормуючи тим самим поведінку людей.

Другий тип нормативності є соціальним засобом самореалізації людини. Це свого роду «надприродна» нормативність, яка за своєю суттю є схемою таких умов або правил поведінки, в рамках яких людська індивідуальність, особистість буде найповніше реалізовуватися. Саме в цьому відношенні переоцінка всіх цінностей, про яку заявив Ніцше, здійснюється найвиразніше. «Надприродна» нормативність виникає як наслідок соціалізації особистості. Відчуваючи потребу в певних правилах або нормах дії, вона переробляє усталені цінності та принципи поведінки і трансформує їх під себе, що дозволяє їй конституювати власну індивідуальність. I саме таке розуміння норм і принципів життя особистості дає нам можливість визначати рамки у яких ми можемо здійснювати самореалізацію. Отже, особистісна ідентичність грунтується на свободі як подоланні і пошуку себе, формуванні власної самості. Таку нормативність можна визначити як «життєву» систему норм і принципів існування. Можна стверджувати, що обидва типи нормативності і формують процес соціалізації особистості і визначають поведінку у ситуаціях невизначеності.

Подальша логіка міркування про відкритість особистості приводить нас до ідеї невизначеності майбутнього i, відповідно, до ризику як невід’ємної характеристики особистості. У соціологічній літературі склалося велика кількість трактувань поняття «ризик». Для нас цікава точка зору, згідно з якою ризик відображає невизначеність, який феноменально існує в свідомості людини. Суть ризикової діяльності полягає в оцінці комплексу можливостей в контінуумі «шанс - небезпека».

У працях Козелецького повністю не виключається гіпотеза, давно сформульована Коганом і Уоллахом (Kogan, Wallach, 1967), згідно з якою існує певна категорія людей, які в ситуаціях, пов'язаних з ризиком, поводяться однаково. Як в заздалегідь програмованих завданнях, так і в завданнях випадкових, вони вважають за краще прийняти однаковий рівень ризику. Таким людям властива постійна готовність до ризику, й у дихотомічних ситуаціях поведінки вони завжди вибирають ризик (Козелецкий, 1979).

Іншими словами, для таких людей функція надання переваги саме ризиковій поведінці $\epsilon$ постійною і не піддається змінам в залежності від виду ситуацій в яких здійснюється прийняття рішень. Однотипність поведінки цих людей в різних ситуаціях може вважатися аргументом, що свідчить на користь концепції про існування окремої характеристики «ризик-риси» (за Санніковою - риси, стійкої в часі, стабільної, але не ситуативної) (Саннікова, 2007).

Внутрішня схильність особистості до ризику часто розглядається, як вроджена. Ця схильність може визначати способи сприйняття ризику і впливати на те, що особистість сприймає як безпечну ситуацію або як загрозливу. Дослідники виявили важливий елемент особистості, що відноситься до ризику - це схильність до пошуку стимулів (нових вражень).

Корнілова, наприклад, також вважає, що при певній схильності до ризику та умов, що підтримують цю схильність, може сформуватися стійка схильність до ризику, яка з часом стає рисою особистості. Подібна риса передбачає оцінку суб'єктом свого минулого досвіду, 3 
точки зору почуття «Я ризикую», результативності і успішності своїх дій в ситуації невизначеності (Корнілова, 2003).

Отже, схильність до ризику, ризикованість або ризик-риса розглядається нами як стійка системна інтегральна властивість особистості, полікомпонентна за своєю структурою, що включає формально-динамічні, якісні, змістовні, соціально-імперативні характеристики. Представляючи, таким чином, схильність до ризику, ми спираємося на континуальний підхід до дослідження структури особистості, запропонований Санніковою (2003, 2007). У контексті даного підходу особистість розглядається як макросистема, що складається 3 різнорівневих підсистем, що мають специфічні характеристики. В структурі виділяються наступні рівні:

- формально-динамічний;

- змістовно-особистісний;

- соціально-імперативний.

До першого рівня відноситься сукупність всіх властивостей, що відображають динаміку протікання психічних явищ та індивідуальні властивості конституційного характеру. Другий включає в себе власне особистісні властивості (поняття особистості у вузькому сенсі слова): спрямованість, потреби, мотиваційну сферу. Третій рівень умовно названий соціально-імперативним, містить клас характеристик, спричинений включенням особистості в різноманітні суспільні, соціальні зв'язки та впливом реального соціального середовища, соціальних норм, культурних традицій тощо. (Саннікова, 2013). Якщо два перших рівня наближені (і вербально, і за змістом) до бачень концепції про двоаспектність психічного (динамічне і змістовне), то третій рівень включає той клас характеристик, які відображають наявні в особистості уявлення про суспільство, норми культури, знання, і саму мораль особистості. Третій рівень чітко контролюється свідомістю.

Межі між рівнями умовні, перехід від одного до іншого утворює певний простір, що об'єднує риси двох сусідніх рівнів. Ці переходи мають свій специфічний зміст. Зона перетину формально-динамічного (перший рівень) і змістовно-особистісного (другий рівень) містить загальні, для обох рівнів, характеристики, які однозначно неможливо віднести тільки до одного з них. Тут виділяються якісні особливості психологічних складових темпераменту і соціальних особистісних утворень. Просторова зона між другим і третім рівнями забезпечує переробку інформації, знання, цілеспрямований вплив зовнішнього світу - індивідуальний досвід, свідомість, самосвідомість. Дані рівні взаємопов'язані між собою і взаємопроникають один в одного. Саме це пояснює розвиток окремих психічних властивостей, які пронизують особистість від нижчих рівнів до вищих (Саннікова та ін., 2007).

До числа таких властивостей можна віднести і ризикованість або ризик-рису. Як властивість особистості вона може проявити себе на всіх її рівнях, на кожному з них має свій специфічний зміст, а значить, є різнорівневою властивістю. При цьому характеристики різних рівнів можуть своєрідно взаємодіяти між собою, доповнюючи один одного i утворюючи цілісну інтегральну властивість. Таким чином, ризикованість як ризик-риса може виступати як системна інтегральна властивість особистості. Ризик являє собою соціальну поведінку суб'єкта, яка відбувається в умовах невизначеності. Невизначеність виступає як констатуюча ознака. Таким чином, виділяються два важливі параметри ризику невизначеність і діалектика дихотомії «успіх - невдача». Ситуація ризику полягає в тому, що особистість потрапляє в умови, коли відсутні готові рішення та способи поведінки. Можливі наслідки ризикованих дій залежать від людини, від іiі рішення і відповідальності за результати втілення цього рішення.

Таким чином, і успіх, і невдача стає надбанням особистості, результатом прийнятого нею рішення та реалізованих дій. Ризикуюча особистість, яка є ціннісним утворенням, не тільки оцінює, але і намагається отримати бажане, оцінюючи при цьому і можливість негативного результату. Можна сказати, що ризик - це ситуація невизначеності, що вимагає від людини повноти відповідальності в зв’язку з можливістю понести втрати. Існує два основні підходи до розуміння ризику - технологічний і соціальний. В рамках першого ризик 
розглядається як атрибут технологій, коли не враховуються суб'єктивні цінності, а результати зводяться до кількісної оцінки ймовірності певних надбань/втрат. Характерною рисою ризику в рамках даного підходу є можливість його оцінки (калькуляції).

Другий підхід вбачає безпосередній зв'язок оцінки ризику з цінностями і нормами соціального характеру і враховує соціокультурний контекст. Саме тому соціальний підхід для нас $є$ пріоритетним. Ризик як стан невизначеності стає і показником відкритості людини майбутньому, її здатності колонізувати майбутнє. Таким чином, ризик входить в життєвий простір особистості, стаючи невід'ємною його характеристикою. Луман, розмірковуючи про сутність ризику, стверджує, що деяких здобутків можна досягти тільки поставивши щось на карту. Порівняти таку ситуацію можна з грою в рулетку, коли приймається рішення, яка буде ставка. Самоконструювання особистості в умовах ризику може вимагати граничної ставки: людина, ризикуючи, йде ва-банк, ставлячи на кін себе, тому ризик в граничному своєму вираженні може розумітися як ризик втрати особистістю власної ідентичності або свого життя в екстремальних ситуаціях.

Висновки та перспективи подальших розвідок. Яким чином відбувається становлення такої системи, системи, що не просто розвивається, але самоорганізовується, тобто перебуває в режимі прогресивного ускладнення, здійсненого й потенційно можливого перетворення, трансформації? Найперше, самоорганізація вимагає від людини розуміння змісту й цінності своїх дій, у чому як раз і проявляється оцінка ризику у ситуації невизначеності та ризиковість людини як особистісна диспозиція. Вирішення важливих завдань, прийняття рішень, здійснення виборів є неможливими без зупинки на життєвому шляху, а для цього особистість повинна зайняти певну позицію, яка буде визначальною у сприйнятті ситуації, підході до розв'язку проблеми. Позиція, у свою чергу, окреслюється життєвим світом людини, який не $є$ статичним, бо випливає 3 постійно присутнього протиріччя між образом світу та способом життя людини.

Таким чином, підводячи підсумок, можна зробити кілька висновків. По-перше, особистість являє собою актуалізацію іiі ціннісної структури в просторово-часовому континуумі. Життєвий простір особистості розуміється нами як сфера ії унікального, неповторного існування, самореалізації. Він являє собою єдність тілесної і часової, просторової і біографічної характеристик. По-друге, свобода, творчість, нормативність i ризик є невід'ємними характеристиками особистості. Свобода трактується нами як подолання себе, пошук і формування власної самості. Нормативність проявляється в двох варіантах: як тілесна і соціальна (статична та динамічна). Соціальна нормативність стає показником відкритості особистості майбутньому, іiі здатності до творчості і вільного та відповідального самотворення. Ризик виникає як показник потенційності та невизначеності результату; він розуміється як показник відкритості особистості. Ризик визначається нами як окрема характеристика особистості, можливість подолати власну обмеженість в самореалізації і яка має можливість визначального впливу на життєвий простір особистості. Тому стратегіями подальшого дослідження $\epsilon$ саме використання експериментальногенетично-транспективного методу з метою вивчення основних можливих ліній прийняття особистістю ризикових рішень через призму самодетермінації особистості в життєвому просторі та вивчення iї ризиковості як диспозиції, як результату соціалізації, самоусвідомлення щодо необхідності опанування жаданими об'єктами, станами чи ситуаціями.

\section{СПИСОК ПОСИЛАНЬ}

Алексєєва, Т. В. (2013). Аналіз психологічних ризиків у процесі розвитку Відповідальності студентів вищої школи: теоретичні засади. Педагогічний процес: теорія $i$ практика, 3, 195-204.

Безродний, А. В. (2010). Схильність до ризику як особистісна детермінанта небезпечної діяльності. Проблеми екстремальної та кризової психології, 7, 37.

Козелецкий, Ю. (1979). Психологическая теория решений. Москва: Прогресс. 
Конюхов, Н. И. (1966). Словарь-справочник практического психолога. Воронеж: Издво НПО «МОДЕК».

Корнилова, Т. В. (2003). Психология риска и принятия решений: Учеб. пособ. для вузов. Москва: Аспект Пресс.

Леонтьев, А. Н. (1983). Образ мира: Избранные психологические произведения в $2 \mathrm{~m}$. (Т. 2, 251-261). Москва: Педагогика.

Леонтьев, Д. А. (1999). Психология смысла: природа, строение и динамика смысловой реальности. Москва: Смысл.

Непомнящий, О., \& Медведчук, О. (2017). Теоретичні аспекти формування та розвитку системи управління ризиками. Ефективність державного управління, 4 (53). Ч. 1.

Рішняк, I. В. (2003). Системний аналіз категорій ризику та невизначеності. Вісник Національного університету "Львівська політехніка", 489, 263-275.

Санникова, О. П. (2007). Пролонгированный подход к исследованию детерминационных процессов. Наука і освіта. Одеса, 6-7.

Санникова, О. П. (2003). Феноменология личности. Одесса: СМИ.

Санникова, О. П., Санников, А. И., \& Быкова, С. В. (2007). Риск и принятие решений. Харьков: ТОВ (Алекс+).

Саннікова, О. П. (2013). Багатовимірна концепція особистості. Проблеми сучасної психологіï, 1, 15-21.

Смирнов, С. Д. (1985). Психология образа: проблема активности психического отражения. Москва: Изд-во Московского ун-та.

Федулова, I. В. (2018). Психологічні аспекти ризик-менеджменту. Стратегічні імперативи сучасного менеджменту (с. 380-385). Київ: ДВНЗ «КНЕУ ім. Вадима Гетьмана».

Kogan, N., \& Wallach, M. (1967). Risky-shift phenomenon in small decision groups: a test of the information - exchange hypothesis. Journal of Experimental Social Psychology, 3, 75-84.

\section{REFERENCES}

Aleksyeyeva, T. V. (2013). Analiz psykholohichnykh ryzykiv u protsesi rozvytku Vidpovidal'nosti studentiv vyshchoyi shkoly: teoretychni zasady [Analysis of psychological risks in the process of development the responsibilities of high school students: theoretical principles]. Pedahohichnyy protses: teoriya i praktyka, 3, 195-204. [in Ukrainian].

Bezrodnyy, A. V. (2010). Ckhyl'nist' do ryzyku yak osobystisna determinanta nebezpechnoyi diyal'nosti [Propensity to risk as a personal determinant of dangerous activities]. Problemy ekstremal'noyi ta kryzovoyi psykholohiyi, 7, 37. [in Ukrainian].

Kozeletskyy, Yu. (1979). Psykholohycheskaya teoryya reshenyy [Psychological decision theory]. Moskva: Prohress, 504. [in Russian].

Konyukhov, N. Y. (1966). Slovar'-spravochnyk praktycheskoho psykholoha [Dictionaryreference book of a practical psychologist]. Voronezh: Yzd-vo NPO «MODEK». [in Russian].

Kornylova, T. V. (2003). Psykholohyya ryska y prynyatyya reshenyy [Psychology of risk and decision making]. Ucheb. posob. dlya vuzov. Moskva: Aspekt Press. [in Russian].

Leont'ev, A. N. (1983). Obraz myra [The image of the world]. Yzbrannye psykholohycheskye proyzvedenyya $v 2$ t. (T. 2, 251-261). Moskva: Pedahohyka. [in Russian].

Leont'ev, D. A. (1999). Psykholohyya smysla: pryroda, stroenye y dynamyka smyslovoy real'nosty [Psychology of meaning: nature, structure and dynamics of semantic reality], Moskva: Smysl, 487. [in Russian].

Nepomnyashchyy, O., \& Medvedchuk, O. (2017). Teoretychni aspekty formuvannya ta rozvytku systemy upravlinnya ryzykamy [Theoretical aspects of formation and development of risk management system]. Efektyvnist' derzhavnoho upravlinnya, 4 (53). Ch. 1. [in Ukrainian].

Rishnyak, I. V. (2003). Systemnyy analiz katehoriy ryzyku ta nevyznachenosti [System analysis of risk and uncertainty categories]. Visnyk Natsional'noho universytetu "L'vivs'ka politekhnika", 489, 263-275. [in Ukrainian]. 
Sannykova, O. P. (2007). Prolonhyrovannyy podkhod k yssledovanyyu determynatsyonnykh protsessov [A prolonged approach to the study of determination processes]. Nauka i osvita. Odesa, 6-7. [in Russian].

Sannykova, O. P. (2003). Fenomenolohyya lychnosty [Phenomenology of personality]. Odessa: SMY. [in Russian].

Sannykova, O. P., Sannykov, A. Y., \& Bykova, S. V. (2007). Rysk y prynyatye reshenyy [Risk and decision making]. Khar'kov: TOV (Aleks+). [in Russian].

Sannikova, O. P. (2013). Bahatovymirna kontseptsiya osobystosti [Multidimensional concept of personality]. Problemy suchasnoyi psykholohiyi, 1, 15-21. [in Ukrainian].

Smyrnov, S. D. (1985). Psykholohyya obraza: problema aktyvnosty psykhycheskoho otrazhenyya [Image psychology: the problem of mental reflection activity]. Moskva: Yzd-vo Moskovskoho un-ta. [in Russian].

Fedulova, I. V. (2018). Psykholohichni aspekty ryzyk-menedzhmentu [Psychological aspects of risk management]. Stratehichni imperatyvy suchasnoho menedzhment (s. 380-385). DVNZ «Kyyiv. nats. ekon. un-t im. Vadyma Het'mana»,. [in Ukrainian].

Kogan, N., \& Wallach, M. (1967). Risky-shift phenomenon in small decision groups: a test of the information - exchange hypothesis. Journal of Experimental Social Psychology, 3, 75-84. [in English].

\title{
RISK AS A COMPONENT OF PERSONAL LIVING SPACE: THEORETICAL CONTEXT
}

\author{
Korniienko Inokentii \\ Doctor of psychological sciences, docent \\ Department of Psychology \\ Mukachevo State University \\ http://orcid.org/0000-0003-1451-4128 \\ DOI https://doi.org/10.35619/praprv.v1i15.201
}

\begin{abstract}
The article is devoted to the problem of the need to establish control over risk factors and uncertainty through a theoretical analysis of the role and position of the risk in the living space of the personality. Various sources of risk meaning in psychology were analysed, the estimation dichotomy of risk / not risk was defined in the article. Traits of a person prone to risk were revealed, they are: poor self-government, weakened instinct of self-preservation, impulsiveness, rigidity, individualism, etc. The question of normative personality, which is a consequence of personal potentiality was defined from two points of view. Specifically: as "bodily" normativeness, which is considered primarily through adaptation, and social "supernatural" normativeness, which arises as a consequence of socialization of the individual. Feeling the need for certain rules or norms of action, a person reviews the established values and principles of behaviour and transforms them to comply with the actual oneself, which allows to constitute own individuality. Risk parameters were identified through the assessment of uncertainty and through the dialectic of the "success - failure" dichotomy. The tendency to risk, a human risk feature as a stable system, as an integral feature of the personality, multicomponent in its structure, which includes formal-dynamic, qualitative, content type and social-imperative characteristics was considered. The connection of risk assessment with values and social norms considering the socio cultural context was analysed. It is emphasized that social normativity becomes an indicator of an individual's openness to the future, its ability to be creative, free, and responsible self-construction. Risk also arises as an indicator of the potentiality and uncertainty of the result of actions. Risk was defined as a separate feature of the personality, the ability to overcome own limitations in selfrealization and which can determine the impact on the living space of the individual.
\end{abstract}

Keywords: risk, riskiness, living space, uncertainty, self-determination.

Стаття надійшла до редакції 27.08.2020 р. 